\title{
A Comparative Study of in vivo Plant and in vitro Callus Extracts of Centratherum punctatum Cass
}

\author{
K. Mercy Madhumitha ${ }^{1}$, J. Anbumalarmathi ${ }^{1^{*}}$, S. Aruna Sharmili ${ }^{1}$, G. Nandhini ${ }^{1}$ \\ and G. Shanmuga Priya ${ }^{1}$
}

${ }^{1}$ Department of Biotechnology, Stella Maris College (Autonomous), Chennai, 600086, India.

Authors' contributions

This work was carried out in collaboration among all authors. Author KMM performed the statistical analysis and wrote the protocol. Author JA designed the study and managed the literature search and wrote the first draft of the manuscript. Authors JA and SAS managed the analyses of the study.

Authors GN and GSP performed the statistical analyses. All authors read and approved the final manuscript.

Article Information DOI: 10.9734/ARRB/2020/v35i330195 Editor(s):

(1) Dr. Bechan Sharma, University of Allahabad, India Reviewers:

(1) Aba-Toumnou Lucie, University of Bangui, Central African Republic.

(2) Esmat Anwar Abou Arab, National Research Center, Egypt. Complete Peer review History: http://www.sdiarticle4.com/review-history/54704

Original Research Article

Received 05 January 2020

Accepted 10 March 2020

Published 18 April 2020

\begin{abstract}
The present study aims at comparative study between plant and callus extract, with respect to analysis of phytochemical constituents, antioxidant, antibacterial activity and cytotoxicity properties of Centratherum punctatum using aqueous medium and different solvents such as, methanol and ethyl acetate. In vitro studies in MS media supplemented with BAP $4.5 \mathrm{mg} / \mathrm{L}+\mathrm{Kn} 4.0 \mathrm{mg} / \mathrm{L}$ has shown the high callus induction percentage of $92.33 \%$ with a maximum callus weight of $1.08 \mathrm{~g}$. The phytochemical analysis of aqueous, methanol and ethyl acetate extract of $C$. punctatum in vivo plant and in vitro callus showed the presence of alkaloids, flavonoids, phenols and carbohydrates. The aqueous extract of both plant and callus showed the presence of tannins, proteins and steroids whereas the methanol extract showed the presence of tannins, amino acids and terpenoids. The ethyl acetate extract showed terpenoids and protein. FTIR analysis of plant and callus aqueous extract had a maximum characteristic band at $3399.87 \mathrm{~cm}^{-1}$ and $3412.73 \mathrm{~cm}^{-1}$ respectively indicating the presence of $\mathrm{N}-\mathrm{H}$ stretching. GC-MS analysis revealed the presence of 11 different compounds in ethyl acetate extracts of plant and the callus extract revealed the presence of 15 different compounds which was absent in the plant extract. Plant extract exhibited maximum total phenol content than callus extract. The in vitro callus extract showed higher DPPH radical scavenging
\end{abstract}


activity with lower inhibition percentage than in vivo plant extract. A maximum zone of inhibition was observed in methanol extract of in vivo plant and in vitro callus (15 mm and $14 \mathrm{~mm}$ respectively) against Bacillus subtilis. The ethyl acetate extract of in vivo plant and in vitro callus had a zone of 14 $\mathrm{mm}$ and $12 \mathrm{~mm}$ against $E$. coli. A maximum zone of inhibition (12 mm and $11 \mathrm{~mm}$ respectively) was observed in both methanol and ethyl acetate of in vivo plant and in vitro callus against Staphylococcus aureus. Antiproliferative analysis revealed that in vivo plant has inhibitory percentage of 23.6 whereas callus exhibited $28.5 \%$ against HeLa cells.

Keywords: Centratherum punctatum; phytochemical; GC-MS; FT-IR; DPPH; antibacterial activity; antiproliferative analysis.

\section{INTRODUCTION}

The medicinal plants have been utilized in the traditional framework of medicine. The social insurance framework dependent on plants goes back to vedic period and nature, instinct and in addition the gathered information over the span of times, has guided the human to find solutions to normal sicknesses from natural sources. The indigenous frameworks of medication to be specific ayurveda, siddha and unani have been in presence for a few hundred of years [1]. As indicated by World Health Organization restorative plants with different life supporting constituents would be the best beginning spot to get an assortment of disturbing, protected and novel medications. The medicinal values of plants lie in some chemical substances to produce a definite physiological action on the humans [2]. Centratherum punctatum is a medicinal plant belonging to the family Asteraceae. It commonly called as lark daisy, kesavardhini, kattushiragam, somraj and brazillian bachelor's button. It is a perennial bushy plant, growing up to 60 to $80 \mathrm{~cm}$ height of well branched stem [2]. It has been an extraordinary asset of medicinal values which are utilized for the treatment of several illnesses. It is rich in secondary metabolites and act as a health promoting compound in anti-inflammatory, antimicrobial, anti-allergic, anti-oxidant and cytotoxic anti-tumour. Thus it is also called as a traditional wound healer [2].

\section{MATERIALS AND METHODS}

\subsection{Plant Material}

Healthy Centratherum punctatum was purchased from botanical garden in Madhavaram, Chennai and authenticated by Dr. N. K. Uday Prakash, Department of biotechnology, Vels University, Chennai and deposited in the herbarium (MLHerb01/2019) at Marina labs. The plants were maintained in the garden.

\subsection{Culture Technique}

Murashige Skoog medium (MS medium) [3], supplemented with $3 \%$ sucrose and $0.8 \%$ agar and different growth hormones such as cytokinin 6-Benzyl amino purine (BAP); kinetin (Kn) for the initiation callus was used for the study. $\mathrm{pH}$ of the media was adjusted to 5.7 before autoclaving.

Table 1. Concentrations of growth regulators by different hormone

\begin{tabular}{lll}
\hline Treatments & \multicolumn{2}{c}{$\begin{array}{c}\text { Concentrations of } \\
\text { growth regulators (mg/L) }\end{array}$} \\
\cline { 2 - 3 } & BAP & Kn \\
\hline $\mathrm{T}_{1}$ & 2.0 & 1.0 \\
$\mathrm{~T}_{2}$ & 2.5 & 1.5 \\
$\mathrm{~T}_{3}$ & 3.5 & 3 \\
$\mathrm{~T}_{4}$ & 4.0 & 3.5 \\
$\mathrm{~T}_{5}$ & 4.5 & 4 \\
$\mathrm{~T}_{6}$ & 3.0 & 1.5 \\
\hline
\end{tabular}

\subsection{Preparation and Inoculation of the Explant}

The nodes $(2-3 \mathrm{~cm})$ were used as explants. It was washed with autoclaved distilled water for 3-4 times, for 10 minutes. This was followed by treatment with surfactant (Tween-20: 2-3 drops/ $100 \mathrm{ml}$ water) for 5 minutes. Explants were then treated with $70 \%$ ethanol for 30 seconds and in the disinfectant $\left(0.1 \% \mathrm{HgCl}_{2}\right)$ for 10 minutes. This was again treated with $70 \%$ ethanol for $2-$ 3 minutes and thrice with autoclaved distilled water. The explants were kept in a petriplate containing Whattmann filter paper to drain out the water [4]. The nodes were inoculated vertically on MS medium for culture initiation. The cultures for indirect regeneration were incubated at $25 \pm 2^{\circ} \mathrm{C}$ under $16 / 8$ hours light regime provided by cool white fluorescent lamp $\left(60 \mu \mathrm{mol} \mathrm{m} \mathrm{s}^{-1}\right)$.

\subsection{Preparation of the Extract}

The in vivo grown plant was collected and shade dried for 2 to 3 weeks. The dried plant materials 
was then ground into a course powder in a mechanical blender and stored in an air tight container. $25 \mathrm{~g}$ of plant powder was subjected to extraction using $250 \mathrm{ml}$ of distilled water (boiled at $100^{\circ} \mathrm{C}$ for 30 minutes). $25 \mathrm{~g}$ of plant powder was subjected separately for extraction in Soxhlet with $250 \mathrm{ml}$ of methanol and ethyl acetate. After the completion of extraction, the extracts were transferred to rotary evaporator to evaporate the solvent and concentrating the extract [5]. The in vitro grown callus was dried under room temperature for 3 days. The dried callus was macerated using mortar and pestle. 10 grams of coarsely macerated callus was subjected separately for the extraction using 100 $\mathrm{ml}$ distilled water and solvent such as methanol and ethyl acetate [6].

\subsection{Total Ash Content}

Silica crucible was heated to red hot for 30 minutes and it was allowed to cool in desiccators. About $2.0 \mathrm{~g}$ of powdered C. punctatum was weighed accurately and evenly distributed among the crucible. The content was shared with a heater and then burnt in a muffle furnace for 2 hours at $600 \pm 10^{\circ} \mathrm{C}$. The crucible was allowed to cool in desiccators. The desiccated, cool basin was then weighed with the ash [7].

$\%$ Total ash $=\frac{\text { Weight of the ash }}{\text { Weight of the sample }} \times 100$

\subsection{Phytochemical Analysis}

The phytochemical tests were carried out for the Centratherum punctatum plant and callus extracts using standard procedures.

\subsubsection{Test for alkaloids}

Dragendroff's test: To $250 \mu$ of the extract, 1 $\mathrm{ml}$ of con. $\mathrm{HCl}$ and few drops of Dragendroff's reagent was added. Formation of red or orange precipitate indicated the presence of alkaloids [7].

Test for flavonoids: To $500 \mu$ l of $2 \mathrm{~N} \mathrm{NaOH} 300$ $\mu \mathrm{l}$ of the extract was added. An intense yellow colour indicates the presence of flavonoids in the sample [8].

Test for phenols: To $250 \mu$ l of the extract, 250 $\mu \mathrm{l}$ of $2 \%$ Ferric chloride solution was added. Appearance of black indicates the presence of phenol in the sample [9].

Test for tannins: To $250 \mu \mathrm{l}$ of the sample was added to $500 \mu$ l of distilled water and filtered few drops of ferric chloride was added to the filtrate. Formation of bluish green or black precipitate indicates the presence of tannins in the sample [10].

Test for steroids: To $250 \mu$ of extract, $250 \mu \mathrm{l}$ of chloroform and $250 \mu \mathrm{l}$ of conc. sulphuric acid was added. Appearance of red colour indicates the presence of steroids [11].

Test for terpenoids: $250 \mu$ of the extract was mixed with $250 \mu \mathrm{l}$ of chloroform followed by the addition of $250 \mu \mathrm{l}$ of conc. sulphuric acid. A reddish brown interface layer formed indicates the presence of terpenoids [7].

Test for quinines: To $250 \mu \mathrm{l}$ of the extract, 250 $\mu \mathrm{l}$ of conc. sulphuric acid was added. Appearance of red colour indicates the presence of quinines [11].

Test for proteins: To $250 \mu \mathrm{l}$ of the extract, 7 drops of millon's reagent was added. Formation of white precipitate that turns red on gentle heating indicates the presence of proteins [7].

Test for amino acids: To $1 \mathrm{ml}$ of the extract, 1 $\mathrm{ml}$ of Ninhydrin reagent were added. Appearance of purple colour indicates the presence of amino acids [7].

\subsubsection{Test for carbohydrates}

Molisch test: Few drops of molish reagent and conc. sulphuric acid were added to the extract, formation of reddish violet ring was observed at the junction of two layers indicates the presence of carbohydrates [11].

Test for saponins: To $250 \mu$ of crude extract, $250 \mu \mathrm{l}$ of water was added. The appearance of stable foam indicates the presence of saponins in the sample [11].

\subsection{Fourier Transform Infrared Spectro- scopy (FT-IR) Analysis}

The aqueous extract of in vivo plant and in vitro callus were subjected to FTIR analysis. The Characteristic peak values were recorded to find out the respective functional groups [7].

\subsection{Gas Chromatography - Mass Spectro- metry analysis (GC-MS)}

The ethyl acetate extract of in vivo plant and in vitro callus of Centratherum punctatum were 
subjected to GC - MS analysis at VIT University, Vellore. Identification of specific components was done by comparing mass spectra and the retention times with the data provided with the NIST library and confirmed [7]. The peak area percentages of the chromatography represent the abundance of the compounds in the extract. The peak area percentage was calculated by the formula:

Peak area percentage ( $\%$ of component) $=$ (area under peak/total area) $\times 100$

\subsection{Total Phenolic Content}

Folin Ciocalteau method was followed for determining the total phenol content in the plant and callus extract of $C$. punctatum of aqueous, methanol and ethyl acetate. Distilled water (500 $\mu \mathrm{l})$ and Folin Ciocalteau reagent $(100 \mu \mathrm{l})$ was added to $1000 \mu \mathrm{l}(1 \mathrm{mg} / \mathrm{ml})$ of the extract and incubated for 6 minutes at room temperature. The final volume was made up to $5 \mathrm{ml}$ with water, after addition of $1.25 \mathrm{ml}$ of $7 \%$ sodium carbonate. The absorbance was measured at $760 \mathrm{~nm}$ using UV - Vis spectrophotometer after an incubation period of 90 minutes. Same method was repeated for other extracts. The total phenol content was expressed as mg Tannic acid equivalents (TAE) per dry weight of the flower using a standard plot of Tannic acid [12].

\subsection{DPPH Radical Scavenging Activity}

Aqueous, methanol and ethyl acetate extract of in vivo plant and in vitro callus of $C$. punctatum of various concentrations of 200, 400, 600, 800, $1000 \mu \mathrm{l}(1 \mathrm{mg} / \mathrm{ml})$ was taken in a test tube and made up to $1 \mathrm{ml}$ using methanol. $1 \mathrm{ml}$ of $0.1 \mathrm{mM}$ DPPH was added to all the test tubes and kept in the dark for 30 minutes at room temperature. The absorbance of the solution was read at $517 \mathrm{~nm}$ in UV visible spectrophotometry. The \% inhibition and $\mathrm{IC}_{50}$ values were calculated with $\mathrm{DPPH}$ as the control and Ascorbic acid as the standard. The concentration of $\mu \mathrm{g}$ of dry weight of material per $\mathrm{ml}$ of solvent $(\mu \mathrm{g} / \mathrm{ml})$ that inhibits the formation of $\mathrm{DPPH}$ radicals by $\mathrm{IC}_{50}$ value [13].

\subsection{Antibacterial Activity}

Two Gram positive organisms Bacillus subtilis, Staphylococcus aureus and one Gram negative organism Escherichia coli were used to determine the antibacterial activity. All the test organisms were maintained on nutrient agar slants in the laboratory. The antibacterial activities of the aqueous, methanol and ethyl acetate extract of $C$. punctatum in vivo plants and in vitro callus were determined by agar well diffusion method. The culture suspension was adjusted by comparing with $0.5 \mathrm{Mc}$ Farland turbidity standard. The plates were swabbed with $100 \mu \mathrm{l}$ of the test organisms. A sterile cork borer was used to make wells of $5 \mathrm{~mm}$ diameters. 5\% DMSO served as the negative control and concentration of $100 \mu \mathrm{l}(1 \mathrm{mg} / \mathrm{ml})$ extract were added into the respective wells. The plates were then incubated at $37^{\circ} \mathrm{C}$ overnight. The resulting zones of inhibition were measured using a ruler calibrated in millimeters. The average of the triplicate reading were taken to be the zone of inhibition of the bacterial isolates [14].

\subsection{Antiproliferative Analysis}

Sub culture of cell line: Concentration of the cell suspension was adjusted by adding $100 \mu \mathrm{l}$ of a $5 \times 105$ cells (HeLa cells)/ml solution to each well and incubated for $24-48$ hours in $\mathrm{CO}_{2}$ incubator.

Drug treatment: $10 \mu \mathrm{l}$ of drug dissolved in DMSO was added to each well. It was placed on a shaking table at $150 \mathrm{rpm}$ for 5 minutes, to thoroughly mix the samples into the media. It was then incubated at $37^{\circ} \mathrm{C}, 5 \% \mathrm{CO}_{2}$ for $12-24$ hours.

MTT assay: $2 \mathrm{ml}$ of MTT solution was added per 96 well plate at $5 \mathrm{mg} / \mathrm{ml}$ in DMSO/PBS. $20 \mu \mathrm{l}$ of MTT solution was added to each well. It was placed on a shaking table at $150 \mathrm{rpm}$ for 5 minutes and incubated at $37^{\circ} \mathrm{C}, 5 \% \mathrm{CO}_{2}$ for 4 hours for MTT metabolization. Formazan (MTT metabolic product) was resuspend in $200 \mu \mathrm{l}$ of DMSO and placed on a shaking table at $150 \mathrm{rpm}$ for 5 minutes. Optical density was read at 560 $\mathrm{nm}$ and subtract background at $670 \mathrm{~nm}$, optical density should be directly correlated with cell quality. The cell density and percentage cell viability was calculated using the following formula.

Cell density $=$ OD Sample - OD blank

The average cell density of triplets:

Percentage of Cell viability $(\%)=\frac{\text { OD sample }}{\text { OD Control }} \times 100$ 


\section{RESULTS AND DISCUSSION}

\subsection{Callus Induction Percentage and Weight}

MS medium supplemented with BAP and $\mathrm{Kn}$ in $\left(\mathrm{T}_{5} \mathrm{MS}+4.5 \mathrm{mg} / \mathrm{L} \mathrm{BAP}+4 \mathrm{mg} / \mathrm{L} \mathrm{Kn}\right)$ showed the highest callus induction percentage (92.33\%) and callus weight $1.08 \mathrm{~g}$ (Fig. 1A) followed by ( $T_{6}$ $3.0 \mathrm{mg} / \mathrm{L} \mathrm{BAP}+1.5 \mathrm{mg} / \mathrm{L} \mathrm{Kn}$ ) showing the highest callus induction percentage $87.54 \%$ and callus weight $0.82 \mathrm{~g}$ (Table 2, Fig. 1B).

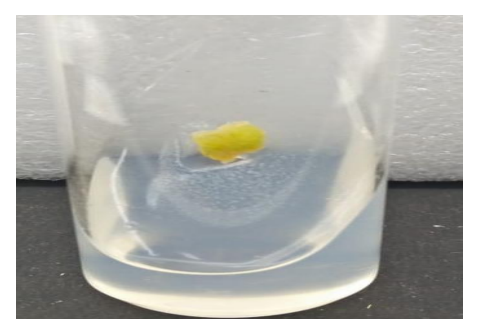

(A)

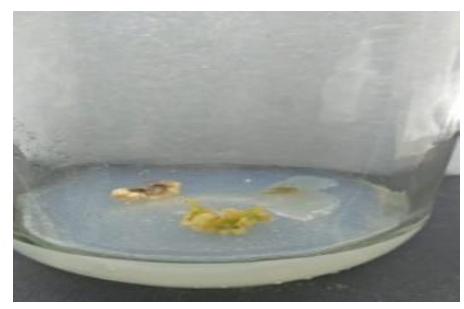

(B)

Fig. 1(A). Callus induction from node explants of Centratherum punctatum on MS medium supplemented with $T_{10}-4.5 \mathrm{mg} / \mathrm{L}$ BAP and 4 $\mathrm{mg} / \mathrm{L} \mathrm{Kn}$. (B) Callus induction from node explants of $C$. punctatum on MS medium supplemented with $T_{11}-3.0 \mathrm{mg} / \mathrm{L}$ BAP and 1.5 $\mathrm{mg} / \mathrm{L} \mathrm{Kn}$

Similarly, Shirin et al. [15] reported in vitro multiple shoot proliferation method for Tridax procumbens L. using nodal explants. MS medium was supplemented with different concentration and combination of plant growth regulators such as BAP, Kn, NAA, IBA and $\mathrm{GA}_{3}$. In nodal segment the highest culture response $95 \%$ was observed. Archana et al. [16] reported the micropropagation of Eclipta alba (L.) Hassk using nodal segment where multiple shoot were obtained by culturing the explants on MS media supplemented with various concentration of BAP and $\mathrm{Kn}$ and in combination with IAA and NAA. The highest culture response was $90 \%$ of shoot induction.

\subsection{Total Ash Content}

C. punctatum is a medicinal plant used by many of the herbal practitioners to treat many diseases. The amount of ash content provides a measure of total amount of mineral matter in a plant. In the present study, it is noted in vivo plant contain maximum of $8 \%$ total ash content. Similarly, Chitra and Brindha [2] reported the C. punctatum possess $10.2 \%$ of total ash. Sivasubramanian and Brindha [17] reported that C. punctatum possess $6.8 \%$ of total ash. Measuring ash content is important because mineral matter may be the cause of pharmacological effect.

\subsection{Phytochemical Analysis}

The aqueous, methanol and ethyl acetate extract of Centratherum punctatum in vivo plant and in vitro callus showed the presence of alkaloids, flavonoids, phenols and carbohydrates. Presence of tannins was observed on aqueous and methanol extract of both plant and callus extract. Steroids was present in aqueous extract of both plant and callus. The presence of terpenoids was noted in methanol and ethyl acetate extract from both plant and callus. The presence of protein was observed in aqueous and ethyl acetate extract from plant and callus. The presence of amino acid were seen in methanol extract of (from) both and callus (Table 3).

Similarly, [2] reported the presence of alkaloids, phenols, quinines, flavones, sterols and protein.

\subsection{Fourier Transform Infrared Spectro- photometer (FT-IR)}

Aqueous plant extract of Centratherum punctatum exhibited a maximum characteristic band at $3399.87 \mathrm{~cm}^{-1}$ and lowest at $538.61 \mathrm{~cm}^{-1}$ indicating the presence of $\mathrm{N}-\mathrm{H}$ stretching and $\mathrm{C}-\mathrm{I}$ stretching deformation respectively (Fig. 2). The aqueous callus extract exhibited a maximum characteristic band at $3412.73 \mathrm{~cm}^{-1}$ and lowest at $557.73 \mathrm{~cm}^{-1}$ indicating the presence of $\mathrm{N}-\mathrm{H}$ stretching and $\mathrm{C}-\mathrm{Br}$ stretching deformation respectively (Fig. 3). Similarly, Naveen and Neelakantan [17] reported the FTIR spectra functional groups with a peak value of alkanes at2927.8, amides at 1564.3, aromatic at 1426.2, aliphatic amines at 1093.6 and alkyl halide at 466.3 for $C$. punctatum. 
Table 2. Effect of various concentrations of BAP and Kn on MS medium for callus initiation of Centratherum punctatum from nodal explants

\begin{tabular}{llllll}
\hline Treatments & \multicolumn{2}{c}{$\begin{array}{c}\text { Concentrations of growth } \\
\text { regulators }\end{array}$} & $\begin{array}{c}\text { No.of days for } \\
\text { callus induction }\end{array}$ & $\begin{array}{l}\text { Callus induction } \\
\text { percentage (\%) }\end{array}$ & $\begin{array}{l}\text { Callus weight } \\
\text { (g) }\end{array}$ \\
\cline { 2 - 5 } & BAP & $\mathbf{K n}$ & & $63.66 \%$ & 0.78 \\
\hline $\mathrm{T}_{1}$ & 2.0 & 1.0 & 4 & $70 \%$ & 0.81 \\
$\mathrm{~T}_{2}$ & 2.5 & 1.5 & 4 & $80 \%$ & 0.62 \\
$\mathrm{~T}_{3}$ & 3.5 & 3 & 4 & $60 \%$ & 0.71 \\
$\mathrm{~T}_{4}$ & 4.0 & 3.5 & 3 & $92.33 \%$ & 1.08 \\
$\mathrm{~T}_{5}$ & 4.5 & 4 & 3 & $87.54 \%$ & 0.82 \\
$\mathrm{~T}_{6}$ & 3.0 & 1.5 & 4 & & \\
\hline
\end{tabular}

Table 3. Phytochemical screening of aqueous, methanol and ethyl acetate in vivo plant and in vitro callus extract of Centratherum punctatum

\begin{tabular}{llllllll}
\hline \multirow{2}{*}{ S. no. } & \multirow{2}{*}{ Phytochemicals test } & \multicolumn{2}{c}{ Aqueous } & \multicolumn{2}{c}{ Methanol } & \multicolumn{2}{c}{ Ethyl acetate } \\
\cline { 3 - 8 } & & Plant & Callus & Plant & Callus & Plant & Callus \\
\hline 1. & Alkaloids & + & + & + & + & + & + \\
2. & Flavonoids & + & + & + & + & + & + \\
3. & Phenols & + & + & + & + & + & + \\
4. & Tannins & + & + & + & + & - & - \\
5. & Steroids & + & + & - & - & - & - \\
6. & Terpenoids & - & - & - & - & + & + \\
7. & Quinines & + & + & - & - & - & - \\
8. & Proteins & + & + & - & - & + & + \\
9. & Amino acids & - & - & + & + & - & - \\
10. & Carbohydrates & + & + & + & + & + & + \\
11. & Saponins & - & - & - & - & - & - \\
\hline \multicolumn{7}{r}{} & \multicolumn{7}{c}{ + indicates positive;-indicates negative) } & &
\end{tabular}

\subsection{Gas Chromatography - Mass Spectro- metry Studies}

In the present study, ethyl acetate extract of in vivo plant $C$. punctatum have revealed the presence of many compounds. Ethyl acetate exacts showed the presence of 1-Octadecyne, 3,7,11,15-Tetramethyl-2-Hexadecan-1-OL,1,1'bicyclopentyl,2-hexadecyl,1-Hexyl-2-

Nitrocyclohexane, Octadeconoic acid, (2-phenyl1,3-dioxolaan-4-YL) Methyl ester,CIS-, Dotriacontane, 2-octadecyl-propane-1,3- DIOL, 2,4,4-Trimethyl-3-Hydroxymethyl-5A-(3-Methylbut-2-Enyl)-cyclohexene, 3-O-Acetyl-6-Methoxycycloartenol, 2-isoprophyl-5-Methylcyclohexyl 3(1-(4- chhlorophenyl)-3-Oxobutyl)-C, 17pentatricontene (Fig. 4). The ethyl acetate extract of in vitro callus $C$. punctatum have revealed the presence of many compounds which were absent in the in vivo plant extract. C. punctatum ethyl acetate callus exacts showed the presence of 7-Dehydrocholesteryl isocaproate, 9,19-
cycloergost-24(28)-EN-3-OL,4,14-Dimethyl-, acetate, (3.BETA., 4.ALPHA., 5.ALPHA.)-, 1,3,3Trimethyl-2-hydroxymethyl-3,3-Dimethyl-4-(3Methylbut-2-Enyl)-cyclohexene, 1,2-pentanediol, 5-(6-bromodecahydro-2-hydroxy-2,5,5A,8Atetramethyl-1-Napthalenyl)-3-Methylene Tetradecane,1-chloro-, 2,6,6-Trimethyl-Bicyclo (3.1.1) Hept-3-ylamine, Cis -9,10Epoxyoctadecan-1-OL, Dodecanal, Hexadecane, 1,16-Dichloro-, 3H-cyclodeca [B] furan-2one,4,9-Dihydroxy-6-Methyl-3,10-Dimethylene, 1-Elcosanol,Heptadecanoic acid, heptadecyl ester (Fig. 5). The GC-MS profile can be used as biochemical markers in the pharmaceutical industries. Few of the compounds in the present study has been shown to have anticancer and antioxidant activity in literature. Similarly, Sivasubramanian and Brindha [17] reported the presence of 30 different compounds along with anti-cancerous compounds such as engenol, sapthulenol, viridifloral, hexadecanoic acid, phthalic acid,bis (7-methylocty) ester, Eicosane and squalene in the GC-MS analysis. 


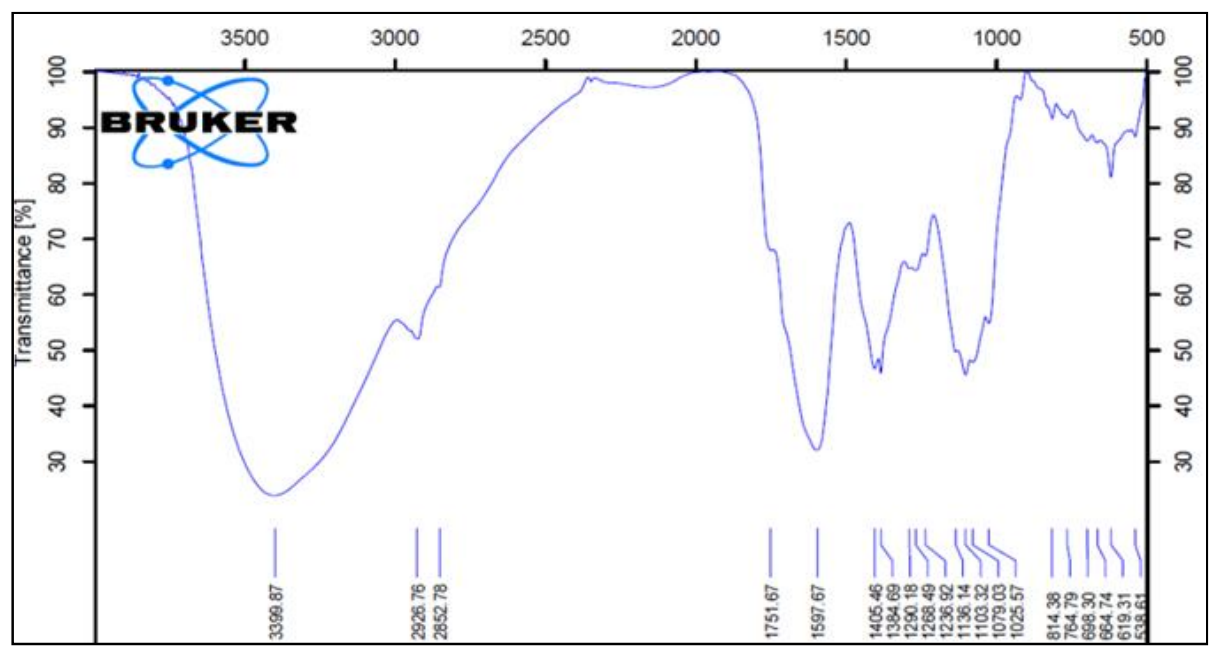

Fig. 2. FTIR spectrum of aqueous in vivo plant extract of Centratherum punctatum

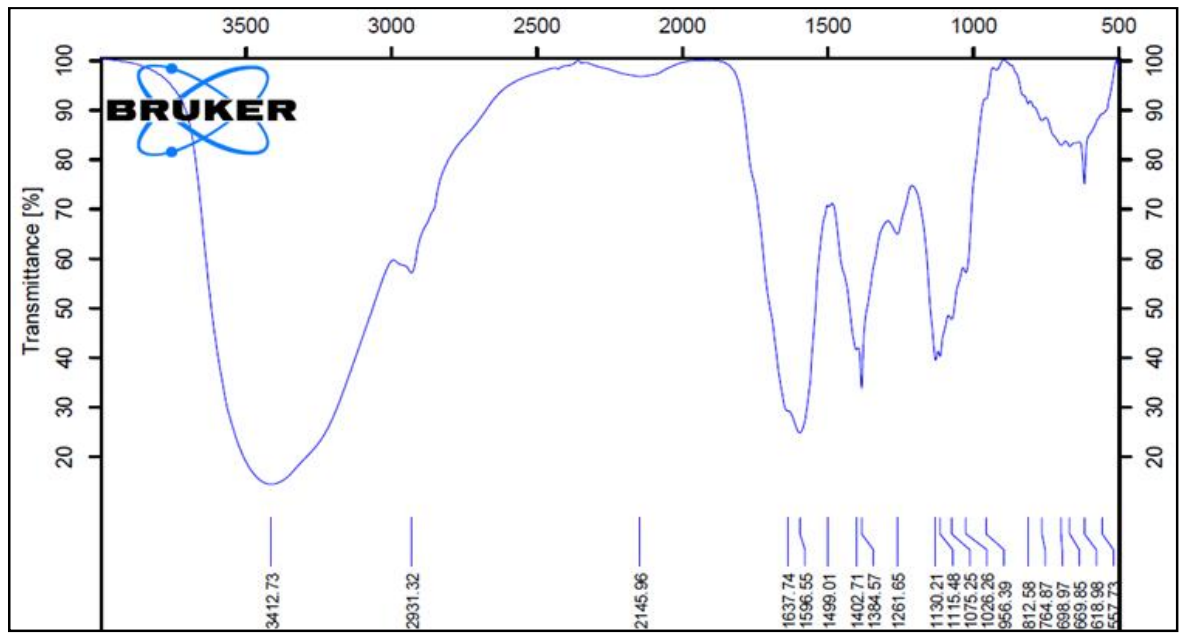

Fig. 3. FTIR spectrum of aqueous in vitro callus extract of Centratherum punctatum

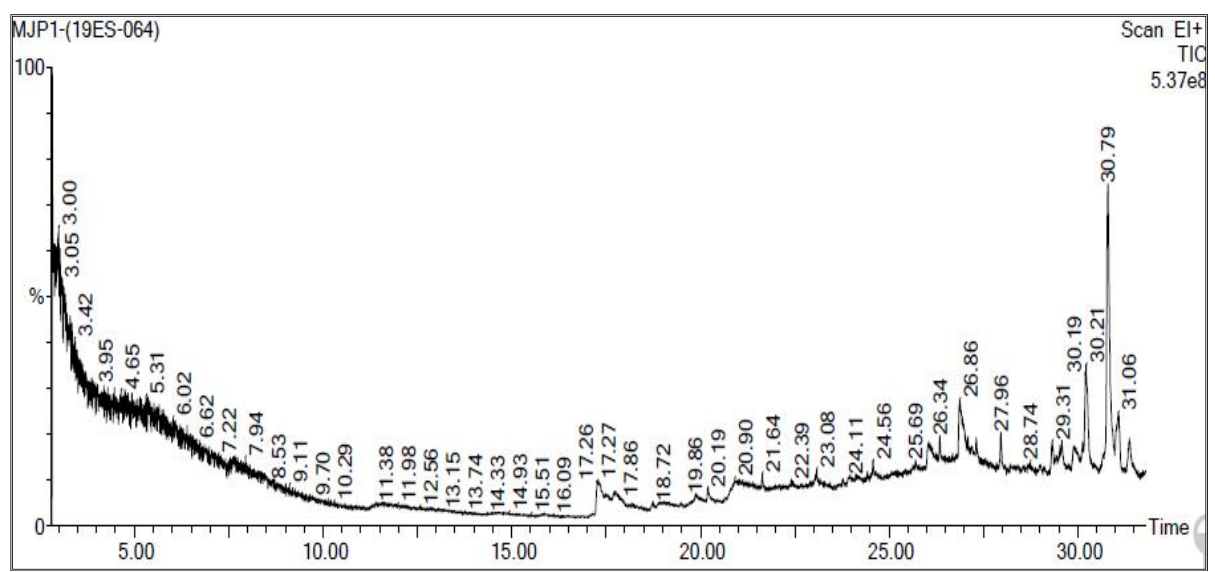

Fig. 4. Chromatogram of ethyl acetate extract of in vivo plant 


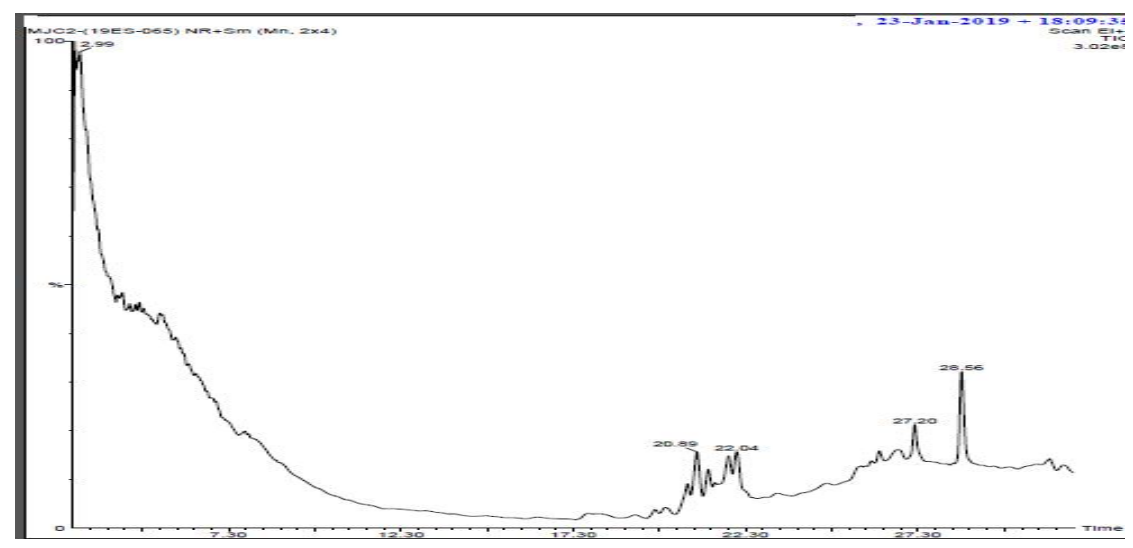

Fig. 5. Chromatogram of ethyl acetate extract of in vitro callus

\subsection{Total Phenol Content}

The total phenolic content for $C$. punctatum $(1000 \mu \mathrm{g} / \mathrm{ml})$ was calculated from the standard graph of tannic acid with the standard curve equation, $Y=17.68 x-0.017, R^{2}=0.973$. The total phenolic content in aqueous extract of in vivo plant and in vitro callus was $79.46 \mathrm{mgTAE} / \mathrm{g}$ dry weight and $69.4 \mathrm{mgTAE} / \mathrm{g}$ dry weight respectively. Methanol extract of plant was 75.79 $\mathrm{mgTAE} / \mathrm{g}$ dry weight and in callus was 64.25 $\mathrm{mgTAE} / \mathrm{g}$ dry weight. Total phenolic content in ethyl acetate extract of plant was $73.3 \mathrm{mgTAE} / \mathrm{g}$ dry weight and callus was $58.03 \mathrm{mgTAE} / \mathrm{g}$ dry weight (Fig. 7) currently, plant materials rich in phenolics are used in the food industry because they decrease the oxidative degradation of lipids and maintain the quality and nutritional value of food. We determined that the total phenolic content was slightly more in the aqueous extract compared to the methanol and ethyl acetate extract.

\subsection{DPPH Free Radical Scavenging Assay}

In the present study, the DPPH radical scavenging activity was found to be efficient in all the three extract such as aqueous, methanol and ethyl acetate extract of both in vivo plant and in vitro callus of $C$. punctatum. The lowest inhibition percentage indicates maximum scavenging activity. The aqueous extract of both plant and callus showed the lowest inhibition of $63.16 \%$ with $\mathrm{IC}_{50}$ value $3.412 \mu \mathrm{g} / \mathrm{ml}$ and $65.10 \%$ with $\mathrm{IC}_{50}$ value $3.257 \mu \mathrm{g} / \mathrm{ml}$ respectively. The methanol extract of both plant and callus showed the lowest inhibition of $60.01 \%$ with $\mathrm{IC}_{50}$ value 3.935 $\mu \mathrm{g} / \mathrm{ml}$ and $60.46 \%$ with $\mathrm{IC}_{50} 3.3 .774 \mu \mathrm{g} / \mathrm{ml}$ respectively. The ethyl acetate extract of both plant and callus showed the highest inhibition of $61.90 \%$ with $\mathrm{IC}_{50}$ value $3.677 \mu \mathrm{g} / \mathrm{ml}$ and $63.68 \%$ with $\mathrm{IC}_{50}$ value $3.463 \mu \mathrm{g} / \mathrm{ml}$ respectively. The in vitro callus extract shows maximum scavenging activity as it has lower inhibition percentage when compared to the in vivo plant extract (Fig. 9). Similarly, Sivasubramanian and Brindha [17] reported antioxidant activity of ethanol extract of aerial plant of $C$. punctatum. The extract also showed significant antioxidant activity comparable with that of standard ascorbic acid in the DPPH free radical scavenging assay.

\subsection{Antibacterial Activity}

The aqueous extract $(1 \mathrm{mg} / \mathrm{ml})$ of $C$. punctatum in vivo plant and in vitro callus was effective against all the three bacteria. The in vivo plant extract and in vitro callus extract had zone inhibition of $14 \mathrm{~mm}$ and $13 \mathrm{~mm}$ against Bacillus subtilis respectively. The in vivo plant extract had a zone of inhibition of $15 \mathrm{~mm}$ against $E$. coli. The in vivo plant extract and in vitro callus extract had a zone of inhibition $11 \mathrm{~mm}$ and $9 \mathrm{~mm}$ against Staphylococcus aureus respectively. The methanol extract $(1 \mathrm{mg} / \mathrm{ml})$ of $C$. punctatum in vivo plant extract and in vitro callus extract had a zone of inhibition of $15 \mathrm{~mm}$ and $14 \mathrm{~mm}$ against Bacillus subtilis respectively. The in vivo plant extract and in vitro callus extract had a zone of inhibition of $14 \mathrm{~mm}$ and $11 \mathrm{~mm}$ against $E$. coli respectively. The in vivo plant extract and in vitro callus extract had a zone of inhibition of $12 \mathrm{~mm}$ and $11 \mathrm{~mm}$ against Staphylococcus aureus respectively. The ethyl acetate extract $(1 \mathrm{mg} / \mathrm{ml})$ of $C$. punctatum vivo plant and in vitro callus extract had a zone of inhibition of $18 \mathrm{~mm}$ and 7 $\mathrm{mm}$ against Bacillus subtilis respectively. The in vivo plant and in vitro callus extract had zone of inhibition of $14 \mathrm{~mm}$ and $12 \mathrm{~mm}$ against $E$. coli respectively. The in vivo plant and in vitro callus extract had zone of inhibition of $12 \mathrm{~mm}$ and 11 $\mathrm{mm}$ against Staphylococcus aureus respectively (Fig. 10). Similarly, Shirin et al. [18] reported that 


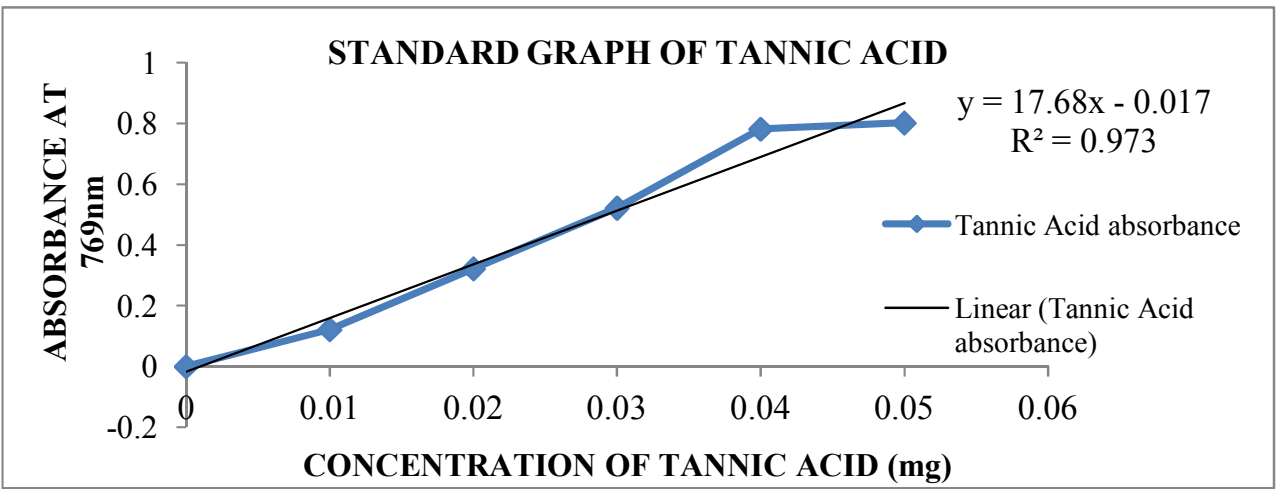

Fig. 6. Total phenolic content standard graph

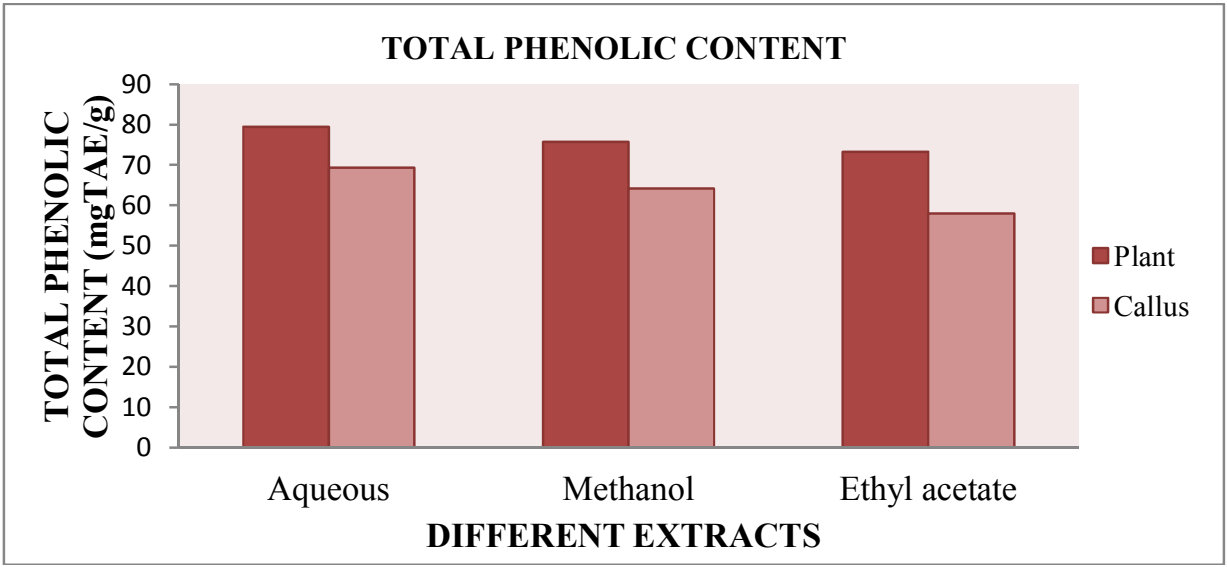

Fig. 7. Total phenolic content of Centratherum punctatum

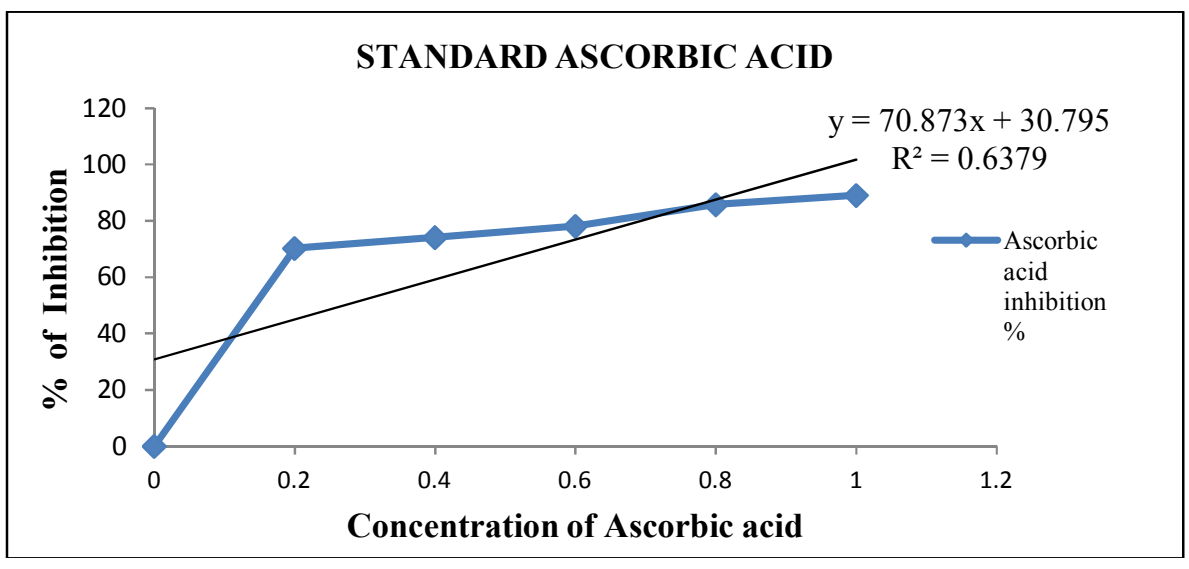

Fig. 8. DPPH free radical scavenging assay standard graph 


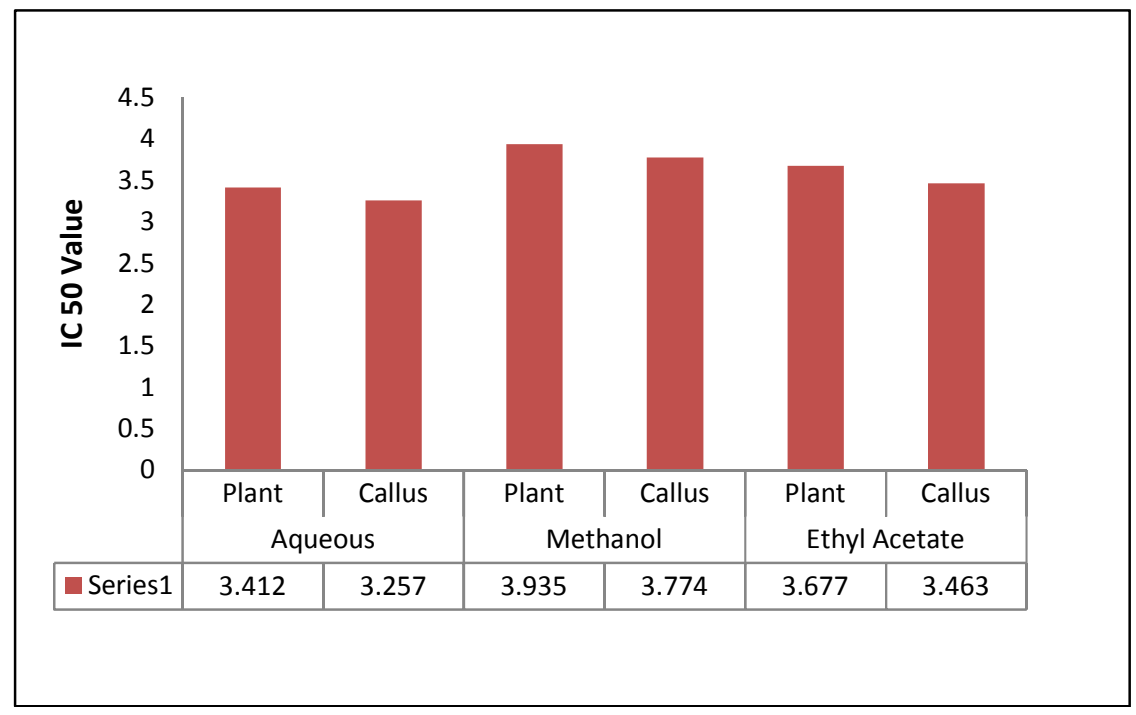

Fig. 9. DPPH free radical scavenging assay IC 50 value of Centratherum punctatum plant and callus of all the extracts

leaf extract of $C$. punctatum showed inhibitory activity against four out of five pathogenic bacteria including the multidrug resistant Acinetobacter baumanii and Staphylococcus aureus. Chitra and Brindha [19] reported antibacterial potential of $C$. punctatum against Staphylococcus aureus, Bacillus subtilis, E. coli and proteus. The maximum activity was observed in aqueous extract when compared with the ethanol extract.

\subsection{Antiproliferative Analysis}

Aqueous extracts of in vivo plant and callus of $C$. punctatum was studied for inhibitory property on
HeLa cell lines by MTT assay. This study revealed that in vivo plant has inhibitory percentage of $23.6 \%$ whereas callus has $28.5 \%$ as inhibitory percentage against HeLa cells (Fig. 11). Thus it shows in vitro callus has more potential to inhibit HeLa cells when compare to plant. Similarly, Sivasubramanian and Brindha [17] reported Cytotoxic effect of Ethanol extract of Centratherum punctatum against Ehrlich Ascites Carcinoma cell lines by incubating with different concentrations exhibited the presence of anticancer fractions such as Eugenol, Spathulenol, Viridiflorol, Hexadecanoic acid, Phthalic acid, bis(7-methyloctyl) ester, Eicosane and Squalene.

\section{Bacillus subtilis}

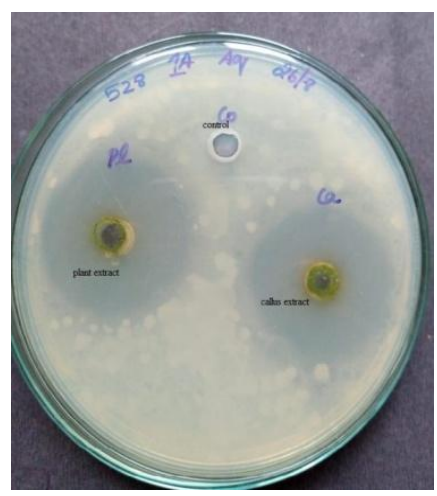

Aqueous

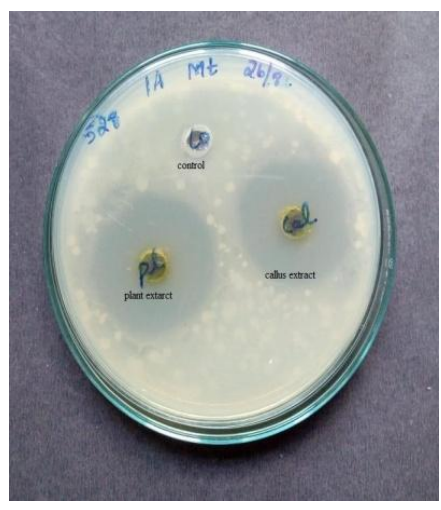

Methanol

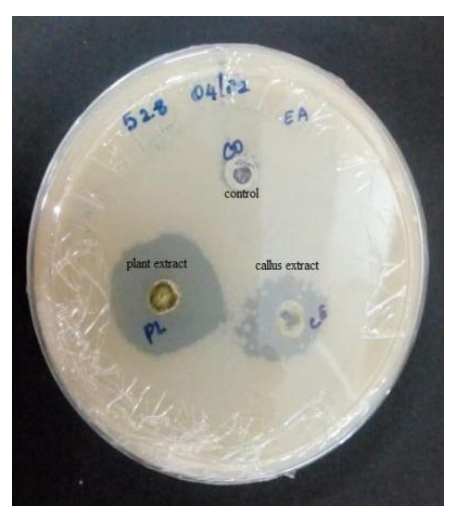

Ethyl acetate 
2. E. coli

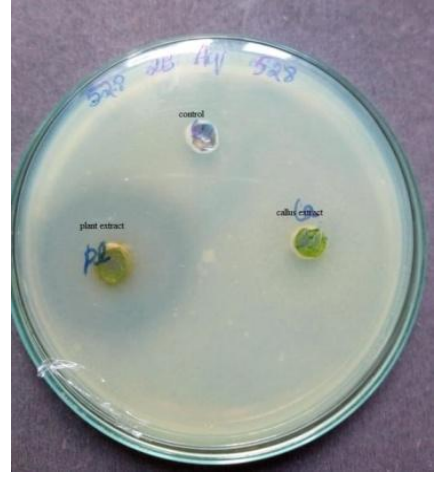

Aqueous

3. Staphylococcus aureus

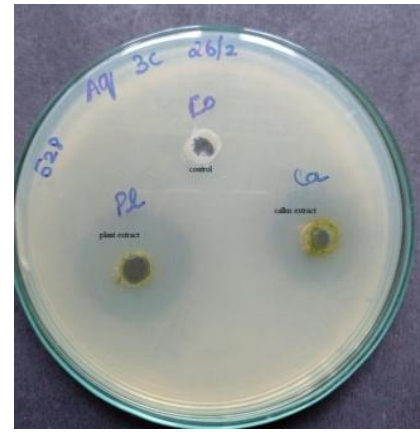

Aqueous

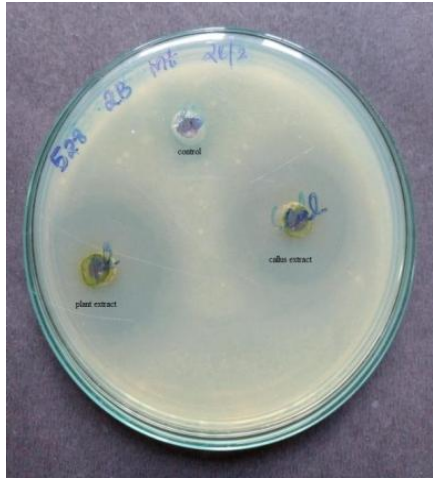

Methanol

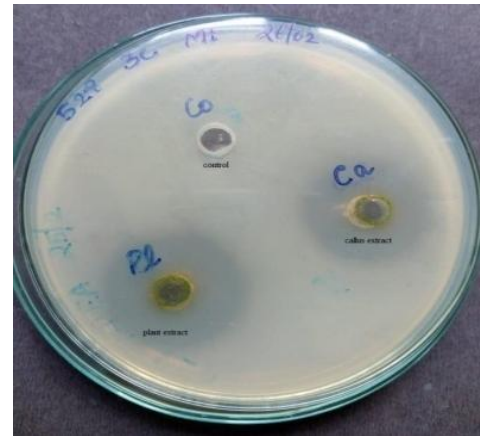

Methanol

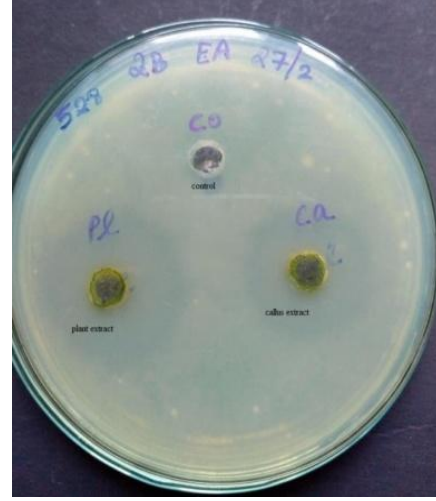

Ethyl acetate

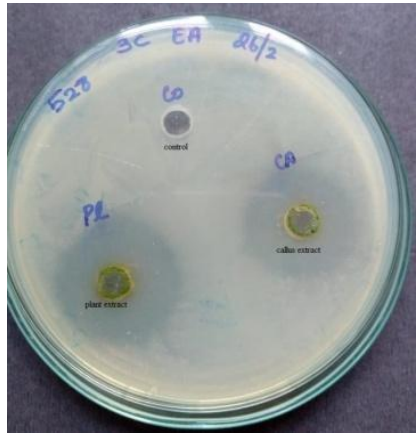

Ethyl acetate

Fig. 10. Antibacterial activity of in vivo plant and in vitro callus extract of aqueous, methanol and ethyl acetate of Centratherum punctatum against

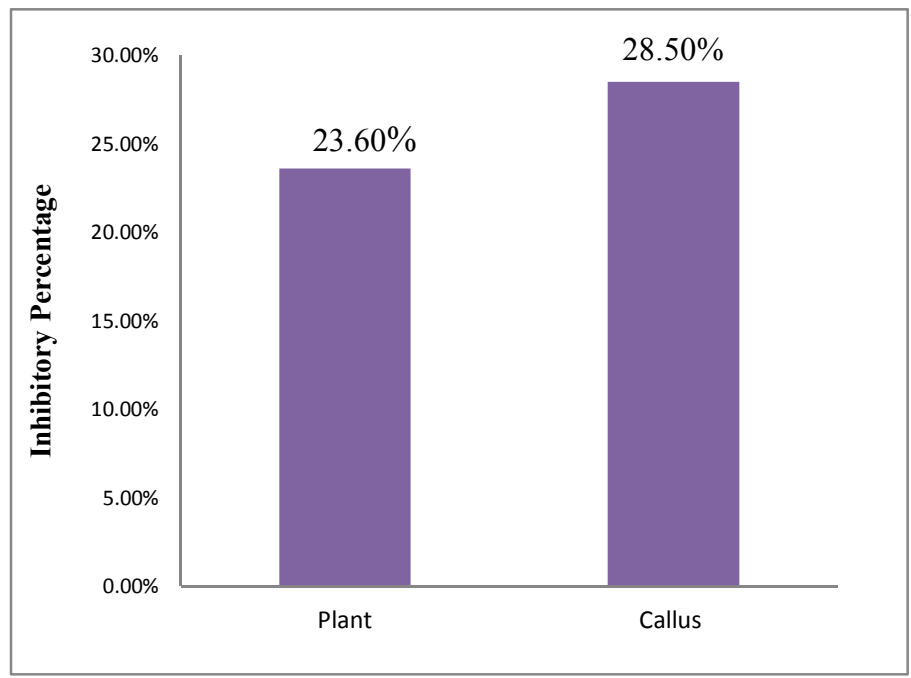

Fig. 11. Antiproliferative analysis of Centratherum punctatum plant and callus against HeLa cells 


\section{CONCLUSION}

Centratherum punctatum has high medicinal properties and has become endangered and is at extinction risk. The regenerated plants can be useful for constant supply of raw materials for secondary metabolite extraction. Maximum content of total ash was found. The preliminary phytochemical screening of aqueous, methanol and ethyl acetate extract of both in vivo plant and in vitro callus of $C$. puntatum revealed the presence of alkaloids, flavonoids, phenols and carbohydrates. FT-IR analysis revealed the presence of some functional constituents in the extract. GC-MS analysis of ethyl acetate extract of both plant and callus revealed the presence of 11 and 15 compounds respectively. Both in vivo plant and in vitro grown callus of aqueous, methanol and ethyl acetate extracts possess potent antioxidant activity. C. punctatum of aqueous, methanol and ethyl acetate extract of both in vivo plant and in vitro callus was more active against the test organism. Anticancer analysis showed a considerable amount of inhibitory percentage against HeLa cells. Thus, the present study revealed the presence of various bioactive compounds indicating that this plant and callus extract compounds can be used as therapeutic drugs.

\section{ACKNOWLEDGEMENTS}

The authors thank the Principal and the Management, Stella Maris College (Autonomous), Chennai for the research facilities. The authors acknowledge DST - FIST for FT-IR facility in CRIST lab, Stella Maris College (Autonomous), Chennai.

\section{COMPETING INTERESTS}

Authors have declared that no competing interests exist.

\section{REFERENCES}

1. Arun Gupta. Ethano botanical studies on Gaddi tride of bharmour area of Himachal Pradesh, (F-2006-04-D); 2006.

2. Chitra B, Brindha P. Studies on preliminary phytochemical screening of different extract of Centratherum punctatum Cass. - Traditional wound healer. International Journal of Pharmacy and Pharmaceutical Science. 2014;6. [ISSN: 0975-1491]

3. Toshio Murashige, Folke Skoog. A revised medium for rapid growth and bio assay with Tobacco tissue culture. Physiologia Plantarum. 1962;15.

4. Vijayakumar M, Vijayakumar R, Stephen R. in vitro propagation of Bacopa monnieri L. A multipurpose medicinal plant. International Journal of Science and Technology. 2010;3(7).

5. Arshad Hussain, Shadma Wahab, Iffat Zarin, Sarfaraj Hussain MD. Antibacterial activity of leaves of Coccinia indica (W. and A) of India. Advances in Biological Research. 2010;4(5):241-248.

6. Syed Zeenat Shaheen, Krishna Bolla, Kandukuri Vasu, Singara Charya MA. Antimicrobial activity of the fruit extract of Coccinia indica. African Journal of Biotechnology. 2009;8(24): 7073-7076.

7. Divya A, Anbumalarmathi J, Aruna Sharmili S. Phytochemical analysis, antimicrobial and antioxidant activity of Clitoria ternatea blue and white flowered leaves. Advances in research Sciencedomain International. 2018;14(15). [ISSN: 2348-0394]

[NLM ID: 101666096]

8. Yadav RNS, Munin Agarwala. Phytochemical analysis of some medicinal plants. J. Phy. 2011;3(12):10-14.

9. Ndam LM, Mih AM, Fongod AGN, Tening AS, Tonjock RK, Enang JE, Fujii Y. Phytochemical screening of the bioactive compounds in twenty Cameronian medicinal plants. International Journal Curr. Microbiol. App. Sci. 2014;3(12):768788.

10. Victor Njoku O, Chidi OBI. Phytochemical constituents of some selected medicinal plants. Afri. J. Pure. Appl. Chem. 2009;3 (11):228-233.

11. Pavithra J, Anbumalarmathi J, Aruna Sharmili S, Jayalakshmi V. In vitro evaluation of phytochemical screening, antioxidant, antibacterial activities and characterization of Carissa spinarum synthesized silver nanoparticles, Biospark International Journal of Innovative Science. 2017;2(2):83-88.

12. Jeniffer Usha $F$, Aruna Sharmili $S$, Anbumalar Matri J. Screening the phytochemical constituents, antimicrobial and antioxidant activities of Acacia nilotica, Ficus benghalensis and Thespesia populnea. European Journal of Biomedical and Pharmaceutical Science. 2018;458463.

[ISSN: 2349-8870] 
13. Soujanya T, Ramalakshmi R, Aruna Sharmili S, Anbumalar Mathi J, Umamaheswari K. In vitro phytochemical analysis and antioxidant activities of minor millets. International Journal of Advanced Life Science (IJALS). 2017; 10(1).

[ISSN: 2277-758x]

14. Anbumalar Mathi J, Aruna Sharmili S, Esther Sharon. Fenugreek (Trigonella foenum-graecum L.): Antimicrobial activity of its phytochemical constituents. International Journal of Ayurvedic and Herbal Medicine. 2016;6:2.

[ISSN: 2166-2171]

15. Shirin Jesmin MD, Abdul Qayum Sarker, M, Firoz Alam. Multiply shoot proliferation in Tridax procumbens L. through in vitro method. International Journal of Bioscience (IJB). 2013;3(7):117-137.

16. Archana Sharma, Shikha Bhansali Ashwani Kumar. Micropropagation of Eclipta alba (L.) Hassk: A important medicinal plant of traditional medicine. International Journal of Life Science and Pharma Research. 2013;3.

17. Sivasubramanian $\mathrm{R}$, Brindha, $\mathrm{P}$. In vitro cytotoxic, Antioxidant and GC-MS studies on Centratherum punctatum Cass. International Journal of Pharmacy and Pharmaceutical Science. 2013;5(3). [ISSN: 0975-1491]

18. Naveen Kumar Pawar, Neelakantan Arumugan. Leaf extract of Centratherum punctatum exhibits anti-microbial, antioxidant and anti proliferative properties. Asian Journal of Pharmaceutical and Clinical Research. 2011;4(4).

[ISSN: 0974-2441]

19. Chitra B, Brindha P. Antimicrobial activity of ethanol and aqueous extract of Centratherum punctatum Cass. World Journal of Pharmacy and Pharmaceutical Science. 2015;4(10).

[ISSN: 2278-4357:1126-1131]

(C) 2020 Madhumitha et al.; This is an Open Access article distributed under the terms of the Creative Commons Attribution License (http://creativecommons.org/licenses/by/4.0), which permits unrestricted use, distribution, and reproduction in any medium, provided the original work is properly cited.

Peer-review history:

The peer review history for this paper can be accessed here: http://www.sdiarticle4.com/review-history/54704 